\title{
SOME NOTES ON THE NON-MARINE MOLLUSCAN FAUNA OF THE HAWAIIAN ISLANDS, WITH DIAGNOSES OF NEW SPECIES.
}

\author{
By C. F. Ancer.
}

Read 13 th January, 1899.

(PLATES XII and XIII, Figs. 8, 16, 20.)

\section{Endodonta (Thaumatodon) nuda, n.sp. Pl. XII, Fig. 1.}

Testa articularis, rotuliformis, depressa, aperte umbilicata (umbilicus sat magnus, circularis, tertio diametri minor), micans, lutea, strigis fuscis in ultimo anfractu fulguratis, inferne evanidis amœne picta, costulis lamellosis confertis, circa umbilicum magis approximatis exarata. Spira plana, anfractus 5 convexi, angusti, lente accrescentes, sutura impressa; ultimus cylindricus, haud deflexus. Apertura vix obliqua, rotundato-lunata, lamellis 2 volventibus in pariete (supera majore) et palatalibus 5 minus prolongatis, æquidistantibus obstructa. Peristoma simplex, acutum, marginibus remotis. Diam. 3 , alt. $1 \cdot 25 \mathrm{~mm}$.

Hab.-Olaa, Central Hawaii (M. Thaanum).

This is a very distinct little form; the armature of the aperture resembles that of $E$. contorta, Fér., of Oahu, but the shell is not hirsute, though quite fresh.

\section{Microcystis sericans, n.sp. Pl. XII, Fig. 5 .}

Testa orbicularis, depressa, imperforata (in loco perforationis minute foveata), tenuis, pellucida, læte cornea, nitens, supra subsericeomicans. Spira obtusa, vix elata, valde depressa, anfractus $4 \frac{1}{2}$, convexiusculi, lente accrescentes, lineis incrementi inconspicuis, sutura superficiali divisi; ultimus mediocriter altus, initio (ad insertionem superam aperturæ et supra peripheriam) obtuse angulatus, postea rotundatus, infra depresso-conrexiusculus. Apertura lunata, fere recta, margine externo cum basali regulariter curvato; columella minute incrassata. Diam. maj. $7 \cdot 33$, min. $6.5 \mathrm{~mm}$; alt. $4 \cdot 25 \mathrm{~mm}$.

Hab.-Olaa, Central Hawaii (Thaanum).

This is very distinct from its nearest ally, M. cicercula, Gould, which is found on a different part of Hawaii. It is more depressed above, has $4 \frac{1}{2}$, not 5 whorls, and a somewhat silky lustre on its upper surface.

\section{Pterodiscus petasus, n.sp. Pl. XII, Fig. 4.}

Testa latissime et perspective umbilicata, sublenticularis, tenuis, luteo-fusca, concolor, vix nitens, ruditer et confertim rugoso-striata, striis lamellosis. Spira late conoidea, lateribus subconcavis, vertice prominulo, obtusiusculo. Anfractus 5, fere plani, sutura lineari et 
parum profunda discreti, regulariter crescentes, ultimus carina superne acuta et alia infra obtusiore circa umbilicum præditus, haud deflexus, superne subdeclivis, infra carinam majorem inverse conicus, planatus. Umbilicus acetabuliformis, conicus ; apertura fere recta, securiformis, ad dextram acute ad basin obtusius angulata, prorsus edentula. Peristoma simplex, rectum, marginibus remotis. Diam. maj. 4.33, min. $3 \cdot 75 \mathrm{~mm}$; alt. $2 \cdot 2 \mathrm{~mm}$.

Hab.-Waianae Mountains, Oahu (Baldwin).

A singular little species, shaped like Endodonta fabrefacta, Pease, of Raiatea, Society Islands, and quite unlike any other species from the Hawaiian Islands, except $P$. digonophorus, Ancey, also of Oahu. The latter, however, is darker, and has a planulate spire.

\section{Thaanumia omphalodes, n. gen. et sp. Pl. XII, Fig. 8.}

Testa aperte umbilicata, ovato-conica, parum nitens, subsericina, tenuis, acute et irregulariter per longitudinem testæ costulata, costulis sublamellosis, leviter flexuosis, intense rufo-cornea, peristomate dilute purpureo. Spira regulariter conica, ambitu rectilinearis, apice subobtusa. Anfractus 6, convexi, regulariter crescentes, sutura impressa divisi, embryonales minutissime spiraliter sculpti, sequentes costulati, interstitiis irregulariter striatuli, ultimus initio subangulatus, ovatus, dilatatus, ad finem minute breviterque subascendens, circa umbilicum angulatus et compressus. Apertura recta, basi recedens, irregulariter ovalis, utrinque angustata. Columella recte descendens, longa, angulo obtuso basi juncta, basi intus leviter contorto-plicata. Peristoma undique expansiusculum, ad columellam magis dilatatum, marginibus haud conniventibus. Long. $6 \cdot 33$, lat. $3.5 \mathrm{~mm}$.; alt. apert. $2.66 \mathrm{~mm}$.

Hab.-Waianae Mountains, Oahu (Baldwin).

Four specimens were found. This very beautiful and striking species is provisionally located in the family Achatinellidæ, though the sculpture of the apex is unlike that of any other genus of the group. Since it could not be placed satisfactorily in any known genus, I venture to propose Thaanumia for its reception. It is well characterized by its peculiar shape, resembling Buliminus Hartungi of the Azores, deep circular umbilicus, thin shell, form of aperture, small basal pillar fold and sculpture, not to speak of the very peculiar striation of the nepionic whorls. It cannot be located in Leptachatina, to which I had formerly referred it.

5. Amastra Frosti, Ancey, var. unicolor, n.var. Pl. XII, Fig. 11.

Testa forma typo similis, sed unicolor stramineo-flavescens, fasciis fuscis omnino destituta.

Hab.-Waianae Mountains, Oahu (Baldwin and others).

\section{Amastra simularis, Hartman.}

Amastra simularis, Hartman: Proc. Ac. Nat. Sci. Philad., 1888, p. 252 , pl. xiii, fig. 7 . 
The type-specimen of this variable species is described as follows:"Shell dextral, ovate conic, whorls $5 \frac{1}{2}$, slightly rounded, body whorl somewhat inflated, two-thirds the length, the first one and a half composed of slightly curved plicæ, suture lightly impressed, epidermis dark brown with black zig-zagged lines and linear striæ, body whorl a dark red colour beneath the epidermis, aperture semi-ovate, dark red, columella straight, with a white twisted plait near the base. L. 15, W. 7, L. apt. 6. Diam. apt. 3 mill. Molokai."

This species, as before remarked, is a protean one, according to Mr. Baldwin, who states (in litt.) that Mr. Sykes' $A$. citrea is but a form of Hartman's shell. The same gentleman also sent me the following varieties, stating that the animals do not vary, the shells only differing in colour and shape. They were both collected in Molokai.

Var. maura, n.var. Pl. XIII, Fig. 16.

Shell much larger and more obese than the type (length 17, width 9, apert. $7 \mathrm{~mm}$.), with 6 whorls. Colour dark red, blackish at the apex, periostracum black, decorticated at some places; columellar margin very dark with a whitish fold; interior of aperture dark purple red.

Var. semicarnea, n.var. Pl. XIII, Fig. 8.

Shell larger than the type, but more slender than var. maura (length $16 \cdot 5$, width $8 \cdot 5$, apert. $6 \mathrm{~mm}$.), with 6 whorls. Apex blackish, the subsequent whorls fulvous, sometimes with straight, somewhat obscured, revolving lines, the lower half of the last whorl yellowish flesh-coloured. Columellar margin bluish, with a white plait. Mouth light-coloured.

It should be remarked that Hartman's original figure is somewhat inaccurate, and does not give an adequate idea of the shell.

\section{Baldwinia, n.subgen. (of Achatinella).}

Testa subgeneri Partulince affinis, sed plerumque tenuior, peristomate parum incrassato et expansiusculo et præcipue plica columellari contorta deficiente discrepans.

Hab.-Hawaii and, perhaps, Oahu and Maui.

Types: Achatinella physa, Newcomb, A. Horneri, Baldwin, A. Hawaiiensis, Baldwin, all from Hawaii. A.grisea, Newc., and A. dubia, Newc., may be referable also to this group; which has been confounded by some with Partulina, and by others with Newcombia, while it appears to stand apart from both. It differs from Perdicella in having a larger shell with expanded and somewhat thickened lip; and I name it after Mr. D. D. Baldwin, who has added so much to our knowledge of the Hawaiian fauna.

\section{Leptachatina isthmica, n.sp. Pl. XIII, Fig. 20.}

Testa subfossilis (an omnino extincta?), pro genere crassiuscula, subopaca, nitens, alba, ultimo anfractu post suturam plerumque 
daucino-rubro, peristomate albo; oblongo-conoidea, læris, lineolis incrementi sub valida lente, minutis, præcipue ad partem superam cujusque anfractus instructa, imperforata vel obtecte subrimata. Spira convexo-attenuata, conoidea, summo minuto, obtusiusculo. Anfractus 7, fere plani, regulariter crescentes, sutura lineari, pellucidomarginata; ultimus oblongus, basi regulariter attenuatus. Apertura subobliqua, oblonga, superne angulata, inferne angustata, plica columellari sat valido munita. Peristoma incrassatum, obtusum, ad columellam supra locum perforationis callose subdilatatum, marginibus callo junctis. Long. 9, diam. $4 \mathrm{~mm}$; alt. apert. $4 \mathrm{~mm}$.

Hab.-Sand Hills, between East and West Maui, with Leptachatina extincta and Tornatellina extincta (Baldwin).

This species has been discovered in a fossil condition only, but may still be living in the island. It is thick for the genus, and the last whorl is more or less stained with red towards the aperture.

\section{Succinea bicolorata, n.sp. Pl. XII, Fig. 2.}

Testa ovalis, perfragilis, pellucida, pallide cornea, ad basin et columellam late rufo-tincta, irregulariter rugoso-striata. Spira pro genere mediocris, conica, pallida, apice subpapillosa; anfractus 3 , haud valde convexi, sutura impressa, celeriter crescentes, ultimo oblongo-ovato. Apertura magna, ovalis, subobliqua, sursim attenuata. Columella haud incrassata, arcuata. Peristoma simplex, parum expansum. Long. $14 \cdot 5$, diam. $9 \mathrm{~mm}$. ; long. apert. $11 \cdot 5 \mathrm{~mm}$.

Hab.-Waimea, Hawaii (Prof. Lyons).

This fine, very thin-shelled species and the next are remarkable on account of the very striking manner of coloration; nothing like it has been hitherto recorded in the genus. Another species, S. Newcombiana, Garrett, has been described from the same district of Waimea; since the description appears to have escaped the notice of all subsequent writers on the subject, and as it was omitted in my paper on the Succinea of the Archipelago, I take the opportunity of transcribing it here.

"Succinea Newcombiana, Garrett.-Shell wide-ovate, very thin, fragile, somewhat inflated, pellucid, whitish horn-colour; body-whorl very large and distinctly striated; spire very small, depressed, with one volution; aperture suborbicular and nearly the whole length of the shell; outer lip much expanded.

"Length: three lines.

"Animal pale flesh-colour, mantle obsoletely fasciated and slightly reflected over the shell. Foot narrow, elongated and minutely speckled with brown.

"Habitat: District of Waimea, Hawaii.

"Observation: This singular species is somewhat rare, and occurs on bushes at an elevation of about four thousand feet above the level of the sea. This species is dedicated to Dr. W. Newcomb, late of Honolulu, S.I." (Garrett, in Proc. Ac. Nat. Sci. Cal., 1857.) 


\section{Succinea Thaanumi, n.sp. Pl. XII, Fig. 3.}

Testa late ovata, fragilis, pellucida, subdepressa, lineis incrementi rugiformibus irregulariter et grosse impressa, rubella vel luteosuccinea, circa columellam late et insigniter rubro-tincta. Spira conoidea, parva, parum producta, apice minuto, obtusiusculo. Anfractus $2 \frac{1}{2}$, celeriter crescentes, convexiusculi, sutura impressa, ultimus multo maximus, late ovalis, testam fere totam æquans. Apertura ampla, lata, margine supero cum dextro arcuatim juncto, extus elliptico, columellari longe arcuato, tenui, absque plica, basali patulo. Long. 15 , lat. $10 \mathrm{~mm}$. ; alt. ap. 13 , lat. ap. $9 \mathrm{~mm}$.

Hab.-Olaa, Hawaii (Thaanum).

A remarkably fine species, allied to the last, but broader, less thin-shelled, more coarsely sculptured, less shining, and with a more diminutive spire of $2 \frac{1}{2}$ whorls only. Named after its discoverer. It recalls to mind Amphibulima patula, Brug.

Var. $\beta$.-Purpurea, unicolor.

\section{Succinea casta, n.sp. (S. venusta, Gould, var. ?)}

Pl. XII, Fig. 10.

Testa oblonga, tenuis, pellucida, succinea (margine columellari interdum rufo-tincto), lineis incrementi rugiformibus, sed lævibus, irregulariter notata, nitens. Spira obtusa, producta, summo valde mamillato, pallida vel rubella. Anfractus $2 \frac{1}{2}-2 \frac{3}{4}$, celerrime crescentes, oblongi, regulares. Apertura obliqua, ampla, ovata, superne attenuata et angulata, basi subrecedens. Columella arcuata, tenuis, plica destituta, margine externo regulariter curvato. Peristoma simplex, acutum, haud patulum. Long. 13-14.5, lat. $7 \cdot 5-8 \cdot 33 \mathrm{~mm}$; long. apert. $9 \cdot 5-10 \mathrm{~mm}$.

Hab.-Olaa, Hawaii (Thaanum).

I do not know Gould's S. venusta, of which S. casta may perhaps prove to be a local race, but according to the description $S$. venusta is smaller, has the last whorl broad and gibbous, which is not the case in $S$. casta; the coloration, also, is not the same, specimens of $S$. casta being more or less reddish around the columella and on the spire, no mention of this being made in Gould's description. Thus I think the species may be conveniently separated.

\section{Succinea Garrettiana, n.sp. Pl. XII, Fig. 7.}

Testa ovata, tenuissima, intense cinnamomeo-rufescens, sericeonitens, irregulariter rugoso-striata. Spira sat brevis, conoidea, obtusa, apice papillata, sutura valde impressa. Anfractus 3, convexi, celeriter crescentes, ultimo magno, ovato, subinflato. Apertura ovata, sursim subattenuata, subobliqua. Columella arcuata, superne indistincte et levissime contortula. Peristoma simplex, acutum, haud expansum. Long. 9.75, lat. $6 \cdot 25 \mathrm{~mm}$.; long. apert. vix $7 \mathrm{~mm}$.

Hab.-Rainbow Falls, Hilo, Hawaii. Found in the gorge of the falls, in very wet places only, on green slimy rocks where water is always trickling down (Baldwin). 
Allied to S. canella, Gould, of Maui, and S. Konaensis, Sykes, of Kona, Hawaii. From the latter it is quite recognizable, being of a warmer colour and less produced spire. It is dedicated to my late distinguished friend and co-worker, Mr. A. Garrett, of Huahine, Society Islands.

\section{Succinea Wainanaensis, n.sp. Pl. XII, Fig. 12.}

Testa elongato-ovalis, tenuis, pellucida, straminea vel pallide succinea, spira plerumque, apice præsertim, pallide rufula, leviter rugoso-striata, striis subflexuosis. Spira pro genere producta, apice papillata, conico-elongata. Anfractus 3, convexi, quasi evoluti; sutura profunda, valde obliqua, antice descendens. Apertura subobliqua, $\frac{2}{3}$ totius testæ subæquans, ovata, superne angulata, margine externo regulariter arcuato, columellari levius arcuato, supra obsolete subplicato, tenui. Callus parietalis in peradultis distinctus. Long. 15, lat. $7.5 \mathrm{~mm}$; long. apert. $9.5 \mathrm{~mm}$.

Hab.-Waianae Mountains, Oahu (Baldwin).

In form it resembles S. pallida, Pfr., of the Society group, and it is quite distinct from any species hitherto detected in the Hawaiian Islands.

\section{Succinea inconspicua, n.sp. Pl. XII, Fig. 9.}

Testa ovalis, tenuis, pellucida, succineo-lutea, lineis incrementi lævibus irregulariter impressa. Spira sat producta, conica, apice minuto, papillari, $\frac{2}{3}$ longitudinis totius adæquans. Anfractus 3, convexi, sutura impressa et satis descendente discreti, rapide crescentes; ultimus ovato-oblongus, subobliquus. Apertura leviter obliqua, regulariter ovalis, superne subangulata. Peristoma simplex, acutum, haud expansum, margine externo arcuato, columellari arcuato, simplici, tenui. Long. 11, lat. $6.25 \mathrm{~mm}$.; alt. apert. $7.5 \mathrm{~mm}$.

Hab.-Waimea, Hawaii (Prof. Lyons).

This species, although of a simpler character than the preceding one, is different from all the Hawaiian species with which I am acquainted. As compared with $S$. Waianaensis, it is smaller and thinner, and the suture is not so oblique, the spire being less produced and papillose.

\section{Melania Baldwini, n.sp. Pl. XII, Fig. 6.}

Testa turrita, solidiuscula, nitide olivacea, unicolor vel persæpe serie punctorum vel macularum parvarum fuscorum infra suturam decorata, apice purpureo-fuscescenti, integro. Spira regulariter conico-attenuata, acuta. Anfractus 12, convexi, sutura canaliculata divisi, superiores lineis incisis spiralibus numerosis et lineis incrementi flexuosis et costulis magis obsoletis crebre decussati, 3 ultimi infra suturam omnino lævigati, postea lineis incisis spiralibus sat distantibus regulariter perarati, intervallis plus minusve crispulatis. Apertura oblonga, intus cærulescenti-livida, elliptica, superne subacuta, basi vix ampliata, 
rotundata ; columella arcuata, incrassata, albido-cærulescens. Long. 30 , lat. $9.5 \mathrm{~mm}$.; long. apert. 10 , lat. apert. $4.66 \mathrm{~mm}$.

Hab.-Lahaina, Maui (Baldwin).

This pretty Melania is allied to M. Oahuensis, Pease, according to Dr. A. Brot, the eminent writer on Melaniidæ, to whom I sent specimens, and who declared them to belong to an undescribed species.

\section{EXPLANATION OF PLATE XII.}

Fig. 1. Endodonta nuda, n.sp.

2. Succinea bicolorata, n.sp.

3. , Thaanumi, n.sp.

4. Pterodiscus petasus, n.sp.

5. Microcystis sericans, n.sp.

6. Melania Baldwini, n.sp.

7. Succinea Garrettiana, n.sp.

8. Thaanumia omphalodes, n. gen. et sp.

9. Succinea inconspicua, n.sp.

10. ,, casta, n.sp.

11. Amastra Frosti, var. unicolor, n.var.

12. Succinea Waianaensis, n.sp. 


\section{$2 \mathrm{BHL}$ Biodiversity Heritage Library}

1899. "Some notes on the non-marine molluscan fauna of the Hawaiian Islands, with diagnoses of new species." Proceedings of the Malacological Society of London 3, 268-274.

View This Item Online: https://www.biodiversitylibrary.org/item/100098

Permalink: https://www.biodiversitylibrary.org/partpdf/40718

\section{Holding Institution}

Field Museum of Natural History Library

\section{Sponsored by}

Smithsonian

\section{Copyright \& Reuse}

Copyright Status: Public domain. The BHL considers that this work is no longer under copyright protection.

This document was created from content at the Biodiversity Heritage Library, the world's largest open access digital library for biodiversity literature and archives. Visit BHL at https://www.biodiversitylibrary.org. 